\title{
Silvicultural performance of five forest species in the central Brazilian Amazon
}

\author{
Murilo Rezende MACHADO ${ }^{1 *}$, Rodrigo CAMARA², Paulo de Tarso Barbosa SAMPAIO ${ }^{3}$, \\ João Baptista Silva FERRAZ ${ }^{3}$, Marcos Gervasio PEREIRA ${ }^{4}$ \\ 1 Instituto Chico Mendes de Conservação da Biodiversidade, Floresta Nacional do Rio Preto, Zona Rural, Conceição da Barra, Brazil \\ 2 Universidade Federal Rural do Rio de Janeiro, Programa de Pós Graduação em Ciências Ambientais e Florestais, Programa Nacional de Pós Doutorado da \\ Coordenação de Aperfeiçoamento de Pessoal de Nível Superior, BR 465, Km 7, Seropédica, Brazil \\ 3 Instituto Nacional de Pesquisas da Amazônia, Departamento de Silvicultura Tropical, Avenida André Araújo, 2936, Manaus, Brazil \\ ${ }^{4}$ Universidade Federal Rural do Rio de Janeiro, Departamento de Solos, BR 465, Km 7, Seropédica, Brazil \\ * Corresponding author: murilo.machado@icmbio.gov.br
}

\section{ABSTRACT}

Planting of forest species of timber interest helps to reduce the deforestation pressure on the Amazon forest, promotes sustainable development of the producing region and generates ecological benefits. The objective of this work was to evaluate the survival rate and growth of four native (Swietenia macrophylla, Parkia decussata, Dipteryx odorata and Jacaranda copaia) and one exotic (Acacia mangium) species in monospecific plantations (spacing of $2 \times 2 \mathrm{~m}$ ) established on areas previously used for grazing, in Itacoatiara, State of Amazonas, Brazil. When the trees were four years old, we collected biometric data [height at $1.30 \mathrm{~m}(\mathrm{DBH}, \mathrm{cm})$, crown projection area $\left(\mathrm{CPA}, \mathrm{m}^{2}\right)$, total height $(\mathrm{H}, \mathrm{m})$, commercial cylinder volume $\left(\mathrm{V}_{\mathrm{cy}}, \mathrm{m}^{3}\right.$ $\left.\mathrm{ha}^{-1}\right)$ ], and qualitative data from visual diagnosis [survival rate $(\mathrm{S}, \%)$, nutritional status (NS, G = good, $\mathrm{D}=\operatorname{deficient} \%$ ), and phytosanitary status (PS, $\mathrm{S}=$ satisfactory, $\mathrm{N}=$ non-satisfactory, \%)]. Three plots of $128 \mathrm{~m}^{2}$, with 32 plants each, were evaluated for each species. Jacaranda copaia, followed by Dipteryx odorata and Parkia decussata, were the recommended species for planting in areas with edaphoclimatic conditions similar to those of the present work, due to their better performance according to most of the variables.

KEYWORDS: dendrometric variables, monospecific plantings, silviculture, tree growth

\section{Desempenho silvicultural de cinco espécies florestais na Amazônia central brasileira}

\section{RESUMO}

Plantios de espécies florestais de interesse madeireiro contribuem para diminuir a pressão sobre a floresta amazônica, proporcionam o desenvolvimento sustentável na região e geram benefícios ecológicos. Este estudo objetivou avaliar a sobrevivência e o crescimento de quatro espécies nativas (Swietenia macrophylla, Parkia decussata, Dipteryx odorata e Jacaranda copaia) e uma exótica (Acacia mangium), em plantios monoespecíficos (espaçamento de 2 x $2 \mathrm{~m}$ ) estabelecidos em áreas anteriormente ocupadas por pastagem, em Itacoatiara, Amazonas. Aos quatro anos de idade, foram obtidos dados biométricos [diâmetro à altura de $1,30 \mathrm{~m}$ do solo $(\mathrm{DBH}, \mathrm{cm})$, área de projeção de copa $\left(\mathrm{CPA}, \mathrm{m}^{2}\right)$, altura total $(\mathrm{H}, \mathrm{m})$, volume comercial do cilindro $\left(\mathrm{V}_{\mathrm{cy}} \mathrm{m}^{3} \mathrm{~h}^{-1}\right)$ ], e dados qualitativos obtidos por diagnose visual [taxa de sobrevivência (S; \%), estado nutricional (NS, G: bom; D: deficiente; \%) e estado fitossanitário (PS, S: satisfatório; NS: não-satisfatório; \%). Para cada espécie considerouse três parcelas de $128 \mathrm{~m}^{2}$, cada uma com 32 plantas. Jacaranda copaia, seguida de Dipteryx odorata e Parkia decussata, foram as espécies mais recomendadas para o plantio em áreas com condiçôes edafoclimáticas semelhantes às do presente trabalho, devido ao seu melhor desempenho para a maioria das variáveis.

PALAVRAS-CHAVE: variáveis dendrométricas, plantios monoespecíficos, silvicultura, crescimento de árvores 


\section{INTRODUCTION}

The Brazilian Legal Amazon, whith an area of six million square kilometers (approximately $60 \%$ of the entire national territory), is known for its rich natural resources. However, estimates indicate that $20 \%$ of the total original forest of the region has already been deforested (IBGE, 2010), in order to serve the interests of the timber industry, among others (Diniz et al. 2009). The situation is currently of major global environmental concern (Vieira et al. 2008). In parallel, the Brazilian participation in the world trade of forest products has been increasing (Silva et al. 2013a), with a predominant participation of the northern states. Large areas of extensive livestock farming have been replaced by forest plantations with native and exotic species, in order to supply the demand for forest products and to comply with environmental legislation (ABRAF 2013).

The above scenario makes reforestation programs a priority to achieve both the decrease of deforestation pressure on the remaining area of primary Amazon forests, maintaining environmental services such as erosion control, carbon sequestration, hidrological balance, biodiversity conservation, and the increase of income for rural properties in the region (Galeâo et al. 2006; Tonini et al. 2006). However, the achievement of these ecological benefits depends on improved information on silvicultural aspects of candidate species for plantation programs, such as stem shape, growth, resistance to pests and nutritional and edaphic requirements, allowing the selection of the more appropriate species (Nascimento et al. 2012). Unfortunately, the information on the silvicultural performance of many exotic species and, especially, native species in Amazonian conditions is still incipient (Costa et al. 2015).

In this context, the objective of this work was to evaluate the silvicultural performance of four native (Swietenia macrophylla, Parkia decussata, Dipteryx odorata and Jacaranda copaia) and one exotic (Acacia mangium) species, in monospecific plantations established on areas previously used for grazing, in Itacoatiara, State of Amazonas, Brazil.

\section{MATERIAL AND METHODS}

The experiment was conducted in the Nova Vida farm (230 ha), located along the State Highway AM-010, km 250, in Itacoatiara, State of Amazonas (AM), Brazil (2०56'13"S, $\left.58^{\circ} 55^{\prime} 56^{\prime} \mathrm{W}\right)$. The climate of the region is type Am (Tropical monsoon), very rainy ( $\geq 2500 \mathrm{~mm}$ per year), with dry winters (Reboita et al. 2010). The relief of the plantation area varied from flat to hilly, and the predominant soil type was classified as Oxisoil (Falesi et al. 1969).

In the 1990's, trees of high economic value were initially removed from the original terra-firme dense ombrophylous forest that covered the area. Afterwards, the remaining vegetation was felled and burned, and the area was sowed with the grass Brachiaria humidicula (Rendle) Schweickerdt for cattle grazing purposes. In December 2003, the owners of the farm isolated part of the pasture ( $36 \mathrm{ha}$ ) in order to install commercial monospecific plantations of five forest species, by means of seedlings. The planted trees were spaced $2 \times 2 \mathrm{~m}$ apart, and four native Amazonian forest species were selected: Dipteryx odorata (Aubl.) Willd. (Fabaceae, non-pioneer, planted area of 0.80 ha), Jacaranda copaia (Aubl.) D Don (Bignoniaceae, pioneer, $5.20 \mathrm{ha}$ ), Parkia decussata Ducke (Mimosaceae, nonpioneer, $2.76 \mathrm{ha}$ ), and Swietenia macrophylla King. (Meliaceae, non-pioneer, $1.60 \mathrm{ha}$ ). Additionally, an exotic species originated from Oceania, Acacia mangium Willd. (Fabaceae, pioneer, $7.50 \mathrm{ha}$ ), was also selected. Machado et al. (2016) provide detailed information on the preparation of the area prior to the establishment of the plantations.

Acacia mangium, Dipteryx odorata and Swietenia macrophylla are considered suitable for cultivation in Amazonian edaphoclimatic conditions because they show high retranslocation rates of phosphorous and nitrogen, which are the most limiting nutrients regarding the low availability to plants in tropical soils (Machado et al. 2016). According to the latter authors, Parkia decussata and Jacaranda copaia both have high retranslocation rates of phosphorous. In monospecific plantations, Swietenia macrophylla is able to enrich the soil availability of potassium and phosphorous, while the soil under Jacaranda copaia presents high values of calcium, sum of bases and $\mathrm{pH}$, up to the depth of $0.30 \mathrm{~m}$ (Machado et al. 2017). In rural properties in the Brazilian Amazon region, Acacia mangium has been planted for the production of wood for export (Barros et al. 2009), whereas Jacaranda copaia has been used to provide thermal comfort for cattle due to shading, and also for the future obtaining of wood, and Dipteryx odorata has been planted for medicinal purposes (Santos and Mitja 2010). Leaves and seeds of Dipteryx odorata are used in the form of tea and also with alcohol maceration, for internal use, to combat headaches, cough, indigestion, and epilepsy (Vázquez et al. 2014).

In December 2006, we established three plots of $128 \mathrm{~m}^{2}$, with 32 trees each, per species plantation. The criteria used to locate the plots were the standardization of the size of the planted areas by species, and similar relief conditions (plan). We considered a completely randomized experimental design with five treatments (species) and three replications (plots) for each species. Initially the following variables were measured: (a) diameter at breast height $(1.30 \mathrm{~m})(\mathrm{DBH}, \mathrm{cm})$, measured with a diametrical tape; (b) total height $\left(\mathrm{H}_{\mathrm{t}}, \mathrm{m}\right)$, measured with a graduated rod; and (c) commercial cylinder volume $\left(\mathrm{V}_{\text {cyl }}, \mathrm{m}^{3} \mathrm{ha}^{-1}\right)$. The $\mathrm{V}_{\text {cyl }}$ was obtained by the equation $V_{c y l}=\mathrm{G}$ $\times H_{t} \times F F$, in which $G$ is the basal area per hectare $\left(\mathrm{m}^{2}\right), H_{t}$ is the mean total height $(\mathrm{m})$ and $F F$ is the average commercial form factor for the species. The $F F$ value was obtained by the equation $F F=O V / C V$, in which $O V$ is the observed volume (rigorous scaling) and $C V$ is the cylinder volume, considering $\mathrm{DBH}$ and the commercial height of the tree. The trees were standing on the ground during this procedure, which is called 
the Smalian method (Soares et al. 2011). Thus, the volume of the stems (with bark) was determined by successive application of the Smalian method on sections 1.0, 2.0 and $3.0 \mathrm{~m}$ long with a diameter limit of approximately $3 \mathrm{~cm}$, using a diametric tape and ruler tape. For this purpose, we scaled two trees of average DBH for each species and plot. The use of a specific $F F$ for each species and site is very important to evaluate volumetric production. Although this factor may contribute to underestimate the commercial volume (Tonini et al. 2006), comparisons between plantings of various species at different sites are more accurate when using this factor.

In December 2007, we measured: (a) survival rate (S, $\%)$; (b) crown projection area $\left(\mathrm{CPA}, \mathrm{m}^{2}\right)$, measured with a measuring tape. CPA was calculated through the ellipse area equation $C P A=P_{b l} \times P_{d P}$ in which $\mathrm{P}_{\mathrm{bl}}$ is the crown projection between planting lines, and $\mathrm{P}_{\mathrm{dl}}$ is the crown projection in the direction of planting line $(\pi=3,14)$. All initial variables $\left(\mathrm{DBH}, \mathrm{H}_{\mathrm{t}}\right.$, and $\left.\mathrm{V}_{\mathrm{cyy}}\right)$ were also measured again. We estimated the mean annual increment per area for height $\left(\mathrm{MAI}-\mathrm{H}_{\mathrm{t}}, \mathrm{m}\right.$ $\mathrm{yr}^{-1}$ ), diameter (MAI-DBH, $\mathrm{cm} \mathrm{yr}^{-1}$ ) and volume (MAI- $\mathrm{ccyl}_{\text {' }}$ $\left.\mathrm{m}^{3} \mathrm{ha}^{-1} \mathrm{yr}^{-1}\right)$, and also the current annual increment per area for height $\left(\mathrm{CAI}-\mathrm{H}_{\mathrm{t}}, \mathrm{m} \mathrm{yr}^{-1}\right)$, diameter (CAI-DBH, $\mathrm{cm} \mathrm{yr}^{-1}$ ) and volume (CAI- $\left.V_{\text {cyl }}, \mathrm{m}^{3} \mathrm{ha}^{-1} \mathrm{yr}^{-1}\right)$, by comparing the results obtained in 2006 and 2007.

We also estimated qualitative variables by visual inspection of the trees (Galeâo et al. 2006): (a) stem bifurcation (B, \%); (b) stem quality (LQ, $\mathrm{R}=$ rectilinear, $\mathrm{T}$ = tortuous); (c) crown quality (CQ, $\mathrm{C}=$ circular, $\mathrm{I}=$ irregular); (d) nutritional status (NS, B = good, D = deficient); and (e) phytosanitary status (PS, $S$ = satisfactory, NS = non-satisfactory).

$\mathrm{DBH}, \mathrm{CPA}, \mathrm{H}_{\mathrm{t}}$ and $\mathrm{V}_{\mathrm{cyl}}$ data were subjected to analysis of variance, followed by the LSD test to compare the means (5\% significance level). Hierarchical cluster analysis (Ward's method) provided a dendrogram for the classification of forest species performance, using the mean values of $\mathrm{DBH}, \mathrm{CPA}, \mathrm{H}_{\mathrm{t}}, \mathrm{V}_{\mathrm{cyl}} \mathrm{S}$, NS-B, PS-S, B, LQ-R for each species. Principal component analysis was performed with the purpose of identifying the biometric variables that correlated with the monospecific plantations. In this latter analysis, we also considered the mean values of soil chemical attributes that were provided by Machado et al. (2017), and excluded the variables or soil attributes that had low correlation $(<0.70 \%)$ with the principal axis 1 or axis 2. Multivariate analyses were carried out using version $2.17 \mathrm{c}$ of the PAST program (Hammer et al. 2001).

\section{RESULTS}

The species presented the following descending order of number of stems (units per hectare): Acacia mangium $(5,138)$ $>$ Dipteryx odorata $(3,020)>$ Swietenia macrophylla $(2,915)>$ Parkia decussata $(2,599)>$ Jacaranda copaia $(2,495)$. Jacaranda copaia had low rates of stem bifurcation and higher rates of both rectilinear stem and circular crown (Table 1). Individuals of this species, as well as of Dipteryx odorata and Parkia decussata, had the highest rates of satisfactory phytosanitary status and good nutritional status (Table 1).

At four years of age, survival rates of all species exceeded $80 \%$, with the exception of Jacaranda copaia, which presented a survival rate $<70 \%$ (Table 1 ). We observed significant differences among the species in DBH $(\mathrm{F}=104.506, \mathrm{p}<$ 0.001) (Table 2). Jacaranda copaia presented a significantly higher mean DBH than the other species, followed by Parkia decussata. Acacia mangium and Swietenia macrophylla presented intermediate mean DBH, while Dipteryx odorata presented the lowest value. This pattern was confirmed by the MAI-DBH and CAI-DBH results, which, in general, tended to be higher for Jacaranda copaia and Parkia decussata, and lower for Dipteryx odorata (Table 3).

Total height varied significantly among the species (F $=186.229, \mathrm{p}<0.001)$ (Table 2). Acacia mangium had the highest mean for this variable, followed by Jacaranda copaia. Dipteryx odorata, Parkia decussata, and Swietenia macrophylla had the lowest values in decreasing order. This pattern was also reflected in MAI- $\mathrm{H}_{\mathrm{t}}$ and CAI- $\mathrm{H}_{\mathrm{t}}$, which had higher values for Jacaranda copaia and Parkia decussata, and lower values for Swietenia macrophylla (Table 3).

The mean CPA differed significantly among the five species $(\mathrm{F}=7.303, \mathrm{p}<0.001)$ (Table 2). Dipteryx odorata, Jacaranda copaia and Parkia decussata had higher mean values of CPA, and did not differ significantly among each other. Acacia

Table 1. Survival rate $(S)$, stem bifurcation ( $B)$, stem quality ( $S Q, R=$ rectilinear, $T=$ tortuous), crown quality $(C Q, C=$ circular, $I=$ irregular), phytosanitary status ( $P S, S=$ satisfactory, $\mathrm{N}=$ non-satisfactory) and nutritional status ( $\mathrm{NS}, \mathrm{G}=$ good, $\mathrm{D}=$ deficient) of five forest species, in 4-year-old homogeneous plantations in Itacoatiara, State of Amazonas, Brazil. Numbers are averages of three replicates. Each replicate was a $128 \mathrm{~m}^{2}$ plot planted with 32 seedlings.

\begin{tabular}{|c|c|c|c|c|c|c|c|c|c|c|}
\hline \multirow{2}{*}{ Species } & \multirow{2}{*}{ S (\%) } & \multirow{2}{*}{ B (\%) } & \multicolumn{2}{|c|}{ SQ (\%) } & \multicolumn{2}{|c|}{ CQ (\%) } & \multicolumn{2}{|c|}{ PS (\%) } & \multicolumn{2}{|c|}{ NS (\%) } \\
\hline & & & $\mathrm{R}$ & $\mathrm{T}$ & $C$ & I & $S$ & $\mathrm{~N}$ & G & D \\
\hline Acacia mangium & 81 & 69 & 6 & 94 & 84 & 16 & 86 & 14 & 87 & 13 \\
\hline Dipteryx odorata & 99 & 17 & 75 & 25 & 90 & 10 & 100 & 0 & 100 & 0 \\
\hline Jacaranda copaia & 68 & 1 & 100 & 0 & 100 & 0 & 100 & 0 & 100 & 0 \\
\hline Parkia decussata & 95 & 3 & 78 & 22 & 83 & 17 & 100 & 0 & 100 & 0 \\
\hline Swietenia macrophylla & 98 & 15 & 71 & 29 & 95 & 5 & 0 & 100 & 71 & 29 \\
\hline
\end{tabular}


mangium and Swietenia macrophylla had the lower values and did not differ significantly between them.

Regarding volumetry, significant differences were observed in the mean $\mathrm{V}_{\text {cyl }}$ among the five species $(\mathrm{F}=111.933$; $\mathrm{p}<$ $0.000)$. Acacia mangium had a $222 \%$ higher $\mathrm{V}_{\text {yl }}$ than the second highest value of Jacaranda copaia (Table 4). Dipteryx odorata and Swietenia macrophylla had the lower $\mathrm{V}_{\text {cyl }}$ values (Table 4). MAI- $\mathrm{V}_{\text {cyl }}$ and CAI- $\mathrm{V}_{\text {cyl }}$ followed the same pattern of $\mathrm{V}_{\text {cyl}}$, resulting in highest values for Acacia mangium and lowest for Dipteryx odorata (Table 4).

Table 2. Mean diameter at $1.30 \mathrm{~m}(\mathrm{DBH})$, total height $\left(\mathrm{H}_{+}\right)$and crown projection area (CPA) of five forest species, in 4-year-old homogeneous plantations in Itacoatiara, State of Amazonas, Brazil. Numbers are averages of three replicates. Each replicate was a $128 \mathrm{~m}^{2}$ plot planted with 32 seedlings. Different letters following the numbers in a column indicate significant differences by the LSD test $(p<0.05)$.

\begin{tabular}{lccc}
\hline Species & $\mathrm{DBH}(\mathrm{cm})$ & $\mathrm{H}_{\mathrm{t}}(\mathrm{m})$ & $\mathrm{CPA}\left(\mathrm{m}^{2}\right)$ \\
\hline Acacia mangium & $8.5 \pm 1.9 \mathrm{c}$ & $13.3 \pm 1.9 \mathrm{a}$ & $1.6 \pm 1.0 \mathrm{~b}$ \\
Dipteryx odorata & $5.2 \pm 1.1 \mathrm{e}$ & $7.1 \pm 1.3 \mathrm{c}$ & $4.6 \pm 1.9 \mathrm{a}$ \\
Jacaranda copaia & $10.9 \pm 2.7 \mathrm{a}$ & $11.3 \pm 2.4 \mathrm{~b}$ & $4.0 \pm 0.6 \mathrm{a}$ \\
Parkia decussata & $9.8 \pm 1.6 \mathrm{~b}$ & $6.6 \pm 1.0 \mathrm{c}$ & $4.4 \pm 2.2 \mathrm{a}$ \\
Swietenia macrophylla & $7.1 \pm 1.4 \mathrm{~d}$ & $5.4 \pm 0.9 \mathrm{~d}$ & $1.7 \pm 0.5 \mathrm{~b}$ \\
\hline
\end{tabular}

Table 3. Mean annual increment and current annual increment of the diameter at $1.30 \mathrm{~m}$ (MAI-DBH and CAI-DBH, respectively) and total height (MAl- $\mathrm{H}_{\mathrm{t}}$ and $\mathrm{CAl}-\mathrm{H}_{\mathrm{t}^{\prime}}$ respectively) of trees of five forest species, in 4-year-old homogeneous plantations in Itacoatiara, State of Amazonas, Brazil. Numbers are averages of three replicates. Each replicate was a $128 \mathrm{~m}^{2}$ plot planted with 32 seedlings.

\begin{tabular}{lcccc}
\hline Species & $\begin{array}{c}\text { MAI-DBH } \\
\left(\mathrm{cm} \mathrm{yr}^{-1}\right)\end{array}$ & $\begin{array}{c}\text { CAl-DBH } \\
\left(\mathrm{cm} \mathrm{yr}^{-1}\right)\end{array}$ & $\begin{array}{c}\text { MAl-Ht } \\
\left(\mathrm{m} \mathrm{yr}^{-1}\right)\end{array}$ & $\begin{array}{c}\text { CAl-Ht } \\
\left(\mathrm{m} \mathrm{yr}^{-1}\right)\end{array}$ \\
\hline Acacia mangium & 2.1 & 1.2 & 3.3 & 5.4 \\
Dipteryx odorata & 1.3 & 1.4 & 1.8 & 2.1 \\
Jacaranda copaia & 2.7 & 2.6 & 2.8 & 4.3 \\
Parkia decussata & 2.4 & 3.0 & 1.7 & 2.4 \\
Swietenia macrophylla & 1.8 & 2.1 & 1.3 & 1.4 \\
\hline
\end{tabular}

Table 4. Commercial form factor (FF), cylinder volume per area $\left(V_{c y l}\right)$, mean annual increment $\left(\mathrm{MAI}-\mathrm{V}_{\mathrm{cyl}}\right)$ and current annual increment $\left(\mathrm{CAI}-\mathrm{V}_{\mathrm{cy}}\right)$ of cylinder volume per area of four native and one exotic tree species, in 4-year-old homogeneous plantations, in Itacoatiara, State of Amazonas, Brazil. Numbers are averages of three replicates. Each replicate was a $128 \mathrm{~m}^{2}$ plot planted with 32 seedlings. Different letters following the numbers in a column indicate significant differences by the LSD test $(p<0.05)$.

\begin{tabular}{lcccc}
\hline Species & FF & $\begin{array}{c}V_{c y l} \\
\left(\mathrm{~m}^{3} \mathrm{ha}^{-1}\right)\end{array}$ & $\begin{array}{c}\text { MAl-V } \\
\left(\mathrm{m}^{3} \mathrm{ha}^{-1} \mathrm{yr}^{-1}\right)\end{array}$ & $\begin{array}{c}\text { CAl-V } \\
\left(\mathrm{m}^{3} \mathrm{ha}^{-1} \mathrm{yr}^{-1}\right)\end{array}$ \\
\hline Acacia mangium & 0.51 & $207.48 \mathrm{a}$ & 51.87 & 120.05 \\
\hline Dipteryx odorata & 0.50 & $25.39 \mathrm{~d}$ & 6.35 & 15.67 \\
$\begin{array}{l}\text { Jacaranda copaia } \\
\text { Parkia decussata }\end{array}$ & 0.42 & $93.57 \mathrm{~b}$ & 23.39 & 57.49 \\
$\begin{array}{l}\text { Swietenia } \\
\text { macrophylla }\end{array}$ & 0.43 & $57.56 \mathrm{c}$ & 14.39 & 37.58 \\
\hline
\end{tabular}

The multivariate hierarchical cluster analysis showed that Dipteryx odorata and Parkia decussata were very similar, with a lower binding distance, and formed a group with a slightly lower similarity (approximately double the previous binding distance) with Jacaranda copaia (Figure 1). Thus, these three species presented higher similarity in relation to the diametric variables (DBH, Ht, CPA, and Vcyl). On the other hand, Dipteryx odorata, Jacaranda copaia and Parkia decussata had lower similarity with the other native species (Swietenia macrophylla). The exotic Acacia mangium presented the lowest similarity to the other species studied.

We registered an intense attack of Swietenia macrophylla (100\% of the individuals) by Hypsipylla grandella (Zeller), which caused the death of older shoots and a super growth of lateral buds.

Principal component analysis grouped the plantations of Dipteryx odorata and Jacaranda copaia in the right portion of the axis 1 (negative values), while the other plantations (Acacia mangium, Parkia decussata, and Swietenia macrophylla) were grouped in the left portion of the axis 1 (Figure 2). The axis 1 explained $70.34 \%$ of the variability of the results. Axis 2 explained $23.93 \%$ of the data variability, and located the plantations of Dipteryx odorata, Jacaranda copaia and Parkia decussata in the upper portion (positive values), and of Acacia mangium and Swietenia macrophylla in the lower portion (negative values) (Figure 2). Overall the PCA explained 94.27\%

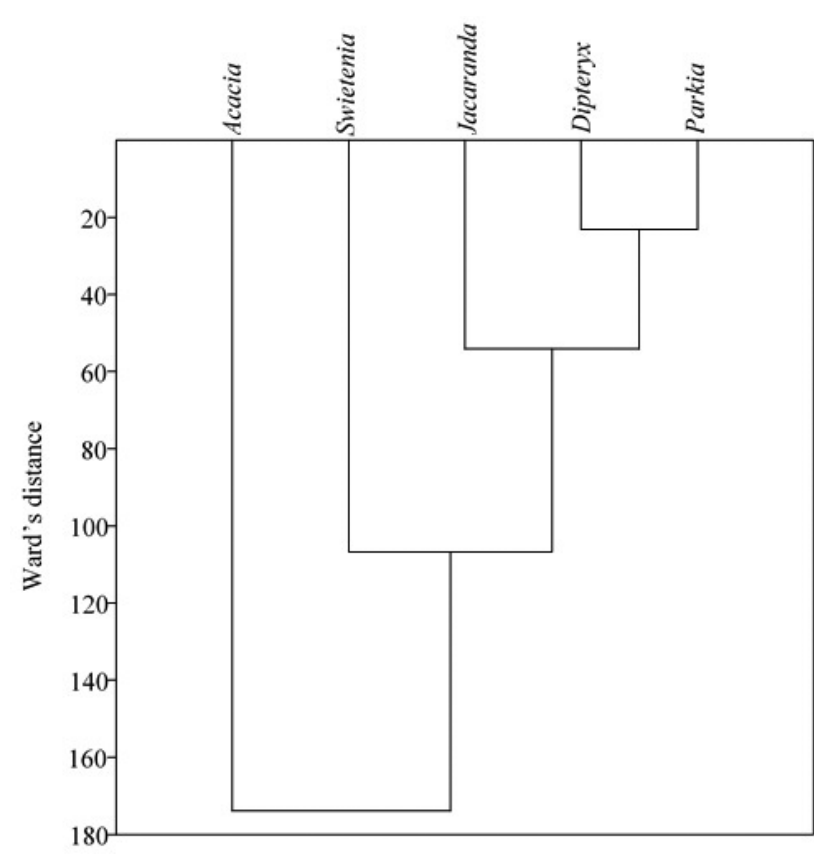

Figure 1. Hierarchical clustering dendrogram for the mean of the dendrometric variables DBH (diameter at breast height, $1.30 \mathrm{~m}$ ), CPA (crown projection area), $\mathrm{H}_{\mathrm{t}}$ (total height) and $\mathrm{V}_{\text {cyl }}$ (commercial cylinder volume) of 4-year-old Acacia mangium, Dipteryx Odorata, Jacaranda copaia, Parkia decussata and Swietenia macrophylla trees in monospecific forest plantations in Itacoatiara, State of Amazonas, Brazil. 


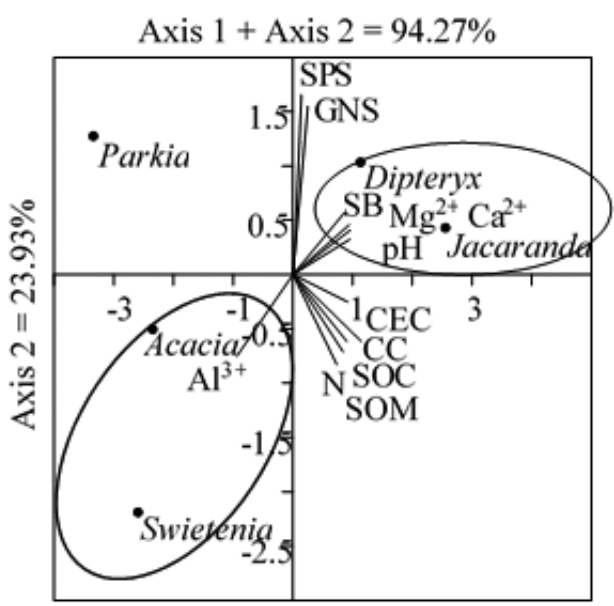

Axis $1=70.34 \%$

Figure 2. Principal component analysis for the mean of some biometric variables of trees (CC: circular crown; SPS: satisfactory phytosanitary status; GNS: good nutritional status), and soil chemical attributes at the depth of $0.00-0.30 \mathrm{~m}$ (provided by Machado et al. 2017), at 4-year-old Acacia mangium, Dipteryx odorata, Jacaranda copaia, Parkia decussata and Swietenia macrophylla monospecific forest plantations in Itacoatiara, State of Amazonas, Brazil. pH; $\mathrm{N} ; \mathrm{Ca}^{2+} ; \mathrm{Mg}^{2+} ; \mathrm{CEC}$ : potential cation-exchange capacity at pH 7.0; SB: sum of bases; SOC: soil organic carbon; SOM: soil organic carbon. of variance in the data. Dipteryx odorata and Jacaranda copaia were both correlated to the values of $\mathrm{Ca}^{2+}, \mathrm{Mg}^{2+}, \mathrm{pH}$, and sum of bases, whereas Acacia mangium and Swietenia macrophylla had correlation with the value of $\mathrm{Al}^{3+}$. We did not observe correlation of Parkia decussata with any soil chemical attributes.

\section{DISCUSSION}

We observed high survival rates (> 80\%) in the majority of the forest monospecific plantations at 4-year-old trees, which indicates a good adaptation to the conditions of the planting site (Nunes et al. 2015). The exception occurred for Jacaranda copaia, which had a survival rate below $70 \%$. Apart from that, this species had the best performance results among all tested species, including both stem and crown quality, phytosanitary and nutritional status, $\mathrm{DBH}, \mathrm{CPA}, \mathrm{H}_{\mathrm{r}}$, and $\mathrm{V}_{\mathrm{cyl}}$.

In comparison with other studies conducted in the Amazon region, our survival rate of Acacia mangium was practically the same as observed in 1-year-old plantations, but lower than in other 4-year-old plantations, and quite higher than 6- and 11-year-old plantations (Table 5). In contrast, the survival rate of Jacaranda copaia was lower in the present study than those observed in older plantations (Table 5).

Table 5. Review of seedling performance of Acacia mangium, Dipteryx odorata, Jacaranda copaia, Parkia decussata and Swietenia macrophylla in the Amazon region. Numbers for survival rate $(\mathrm{S})$, total height $\left(\mathrm{H}_{\mathrm{t}}\right)$, diameter at $1.30 \mathrm{~m}(\mathrm{DBH})$, and cylinder volume per area $\left(\mathrm{V}_{\mathrm{cy}}\right)$ are mean values

\begin{tabular}{|c|c|c|c|c|c|c|}
\hline \multirow{2}{*}{ Species/source } & Spacing & Age & $S$ & $H_{t}$ & DBH & Vcyl \\
\hline & $\mathrm{m}$ & years & $\%$ & $\mathrm{~m}$ & $\mathrm{~cm}$ & $m^{3} h a^{-1}$ \\
\hline \multicolumn{7}{|l|}{ Acacia mangium } \\
\hline Miranda and Valentim (2000) & $1.5 \times 1.5$ & 1 & 80.0 & 2.87 & - & - \\
\hline Souza et al. (2004) & $3 \times 2$ & 4 & 100.0 & 14.0 & 9.5 & 181.3 \\
\hline Tonini et al. (2006) & $3 \times 2$ & 6 & 25.6 & 11.4 & 12.3 & 76.8 \\
\hline Souza et al. (2008) & $3 \times 3$ & 11 & 27.8 & - & - & - \\
\hline Souza et al. (2010) & $3 \times 3$ & 6 & 30.6 & 14.5 & 24.4 & - \\
\hline This study & $2 \times 2$ & 4 & 81.0 & 13.3 & 8.5 & 207.5 \\
\hline \multicolumn{7}{|l|}{ Dipteryx odorata } \\
\hline Souza et al. (2008) & $3 \times 3$ & 11 & 80.6 & 10.4 & 9.6 & 48.6 \\
\hline Souza et al. (2010) & $3 \times 3$ & 6 & 86.1 & 8.1 & 6.6 & - \\
\hline This study & $2 \times 2$ & 4 & 99.0 & 7.1 & 5.2 & 25.4 \\
\hline \multicolumn{7}{|l|}{ Jacaranda copaia } \\
\hline \multirow[t]{2}{*}{ Sampaio et al. (1989) } & $3 \times 4$ & 9 & 63.0 & 13.47 & 18.83 & 12.7 \\
\hline & $4.5 \times 4$ & 9 & 79.0 & 19.43 & 23.53 & 10.3 \\
\hline Tonini et al. (2006) & $4 \times 3$ & 5 & 73.4 & 7.6 & 10.1 & 17.9 \\
\hline This study & $2 \times 2$ & 4 & 68.0 & 11.3 & 10.9 & 93.67 \\
\hline \multicolumn{7}{|l|}{ Parkia decussata } \\
\hline This study & $2 \times 2$ & 4 & 95.0 & 6.6 & 9.8 & 57.6 \\
\hline \multicolumn{7}{|l|}{ Swietenia macrophylla } \\
\hline Souza et al. (2008) & $3 \times 3$ & 11 & 36.1 & 12.0 & 16.1 & 136.4 \\
\hline Souza et al. (2010) & $3 \times 3$ & 6 & 50.0 & 7.7 & 10.9 & - \\
\hline Escalante et al. (2012) & $5 \times 5$ & 1 & 26.9 (site 1); 78.0 (site 2) & 3.9 (site 1); 8.1 (site 2) & - & - \\
\hline This study & $2 \times 2$ & 4 & 98.0 & 5.4 & 7.1 & 42.9 \\
\hline
\end{tabular}


Acacia mangium presented at least four times more stem bifurcations and three times more tortuous stems than the native species in our study, which was also observed by Tonini et al. (2006). Both characteristics are desirable for biomass production. Acacia mangium has a tendency to form multiple trunks, thus the individuals of this species presented the highest number of stems (units per hectare), while the other studied species had lower and similar values. Tonini et al. (2006) also observed a $45.7 \%$ stem bifurcation in Jacaranda copaia, while we had practically no stem bifurcation, nor tortuous stems, for this species in our study. Tree species with rectilinear stems are indicated for the production of lumber and laminates (Trevisan et al. 2013).

Apart from plantation age, the variability in performance within species observed in Table 5 may also have been influenced by differences in other parameters, such as spacing, soil characteristics, climatic conditions, quality of seedlings, and preparation of the planting area (Barbosa et al. 2003). In 16-year-old monospecific plantations of Jacaranda copaia in Manaus (Amazonas State) the survival rates of trees, as well as DBH, increased with increased spacing (Sampaio et al. 1989).

Despite their comparatively low rates of stem bifurcation $(<20 \%)$, Dipteryx odorata and Swietenia macrophylla probably require the removal of the less vigorous branch of the bifurcation to obtain straight and more vigorous stems. These species can be used for furniture production and finishing articles, since they have noble wood with easy workability (Almeida et al. 2010; Zau et al. 2014).

The competition among plants may also affect seedling survival. In Bolivia, survival rates in two 1-year-old plantations (5 x 5 m spacing) of Swietenia macrophylla were $26.9 \%$ and $78 \%$, and were likely related to a higher herbaceous and shrub cover in the former plantation site (Escalante et al. 2012), since Swietenia macrophylla is a gap-demanding species (Dias and Marenco 2006).

The large CPA observed in Dipteryx odorata, Parkia decussata and Jacaranda copaia is a desirable characteristic in forest plantations, since the tree crown is responsible for reducing the direct impact of raindrops and the direct incidence of solar radiation on the soil (Ignácio et al. 2007). Therefore, a rapid soil cover contributes to the stabilization of soil aggregates and the reduction of weed-control costs. Besides, circular crowns, as is the case with Jacaranda copaia, are considered an interesting silvicultural feature, because they have uniform growth, thus favoring the planning of more efficient spacing between trees (Condé et al. 2013). The low values of CPA for Acacia mangium and Swietenia macrophylla were probably related to high competition among the trees, due to the high number of stems per hectare (5138 stem ha$\left.{ }^{1}\right)$. Among Acacia mangium trees, $14 \%$ had signs of fungal infection, which may hinder the growth of this species in plantations (Halfeld-Vieira and Nechet 2010).
We expected to observe an increase in CPA in Swietenia macrophylla, because of the super growth of lateral buds caused by the attack of all of the individuals by Hypsipylla grandella. The appearance of numerous lateral branches reduces significantly the commercial value of the wood of this species (Souza et al. 2008). Thus, the attack by the insects compromised the nutritional status of the trees, which inhibited the vigorous growth of several shoots and also contributed to the low growth in height and diameter of Swietenia macrophylla, in comparison to the other species. The strong smell of young trees of Swietenia macrophylla attracts this moth, that lays its eggs on the shoots, usually on the dorsal surface of leaves, originating caterpillars that cause serious damages to the apical meristem, delaying growth, and even leading to the death of affected plants after successive attacks (Lunz et al. 2009). Attacks of $H$. grandella contributed to the low survival (36.1\%) of Swietenia macrophylla in plantations in Manaus (Souza et al. 2008). Therefore, monospecific plantations of Swietenia macrophylla should be avoided and the planting of this species should only occur if measures are taken to minimize this problem, such as intercropping with Jacaranda copaia, Parkia decussata or Dipteryx odorata, since the diversification of forest species and agroforestry systems considerably reduce infestation in Swietenia macrophylla trees (Silva et al. 2013b). The overwhelming satisfactory phytosanitary and nutritional status of the other three native species indicated that they had higher resistance to pests and pathogens, which is a relevant information about the scarcely known nutritional requirements of native forest species of the Amazon biome (Santos Filho et al. 2007).

Our height values of Acacia mangium were similar, whereas the values of $\mathrm{DBH}$ and $\mathrm{V}_{\text {cyl }}$ were lower, compared to those obtained for older plantations (Table 5). Four-year-old plantations of Acacia mangium with increased spacing ( $3 \times 2$ $\mathrm{m})$ had higher values of DBH $(9.5 \mathrm{~cm})$ (Souza et al. 2004) than in this study, because a wider spacing positively affects the diameter growth of trees (Nascimento et al. 2012). Souza et al. (2008) did not evaluate the growth of Acacia mangium in 11-year-old plantations because the survival rate was too low $(<30 \%)$, and recommended that this species should be harvested between 3 and 5 years of age in monospecific plantations, when their survival rate was $66.7 \%$ and 36.1 $\%$, respectively. Their results probably were influenced by the occurrence of shoot and stem breaks, and windblow falls of trees higher than $6 \mathrm{~m}$.

The values of both height and DHB of Dipteryx odorata, Jacaranda copaia and Swietenia macrophylla in our study tended to be higher than those of older plantations (Table 5). In 11-year-old monospecific plantations of ten native and exotic forest species in Manaus, the lowest values of height, DBH and cylinder volume occurred for Dipteryx odorata (Souza et al. 2008). This pattern is probably a characteristic of this species, which grows mainly in primary forests and 
has high wood density, one of the most resistant among Amazonian timber species (Stangerlin et al. 2013). The DBH growth of Jacaranda copaia did not differ significantly among different spacings (Sampaio et al. 1989). The species also responded with higher DBH values when the soil was harrowed (Barbosa et al. 2003). Successful plantation results have raised the interest in Jacaranda copaia as a silvicultural species in the Amazon region (Tonini et al. 2008).

We found no results for diametric growth of Parkia decussata seedlings in the literature. However, Salomão et al. (2014) recommended the use of this species in forest restoration after mining in conservation units in Amazonia, because its seedlings had $100 \%$ survival after 13 years. The good diametric growth of Parkia decussata, combined with its excellent debranching (Murilo Rezende Machado, personal observation), and low frequency of stem bifurcation or tortuous stems, rendered this species as suitable for the production of lumber. In the State of Roraima, a 5-year-old plantation (4 x $3 \mathrm{~m}$ spacing) of Parkia multijuga Benth. had higher DBH $(12.3 \mathrm{~cm}$ ) (Tonini et al. 2006) than Parkia decussata in the present study.

The high values of both MAI-H $\mathrm{H}_{\mathrm{t}}$ and CAI- $\mathrm{H}_{\mathrm{t}}$ for Acacia mangium and Jacaranda copaia indicated that, at four years of age, these species would already require a wider spacing to maintain and to stimulate their current annual increment in diameter. At least in the case of Acacia mangium, this pattern was corroborated by the high rate of stem bifurcation, which implies intense competition for light. The rapid growth in height of Acacia mangium, also reported by Miranda and Valentim (2000), may be influenced by the high capacity of this species to explore the nutritional pool in the soil, which causes soil acidification due to cation depletion (Yamashita et al. 2008).

Generally, $\mathrm{V}_{\mathrm{cyl}}$ of Dipteryx odorata increased with the age of plantations, while that of Jacaranda copaia and Swietenia macrophylla decreased in older plantations (Table 5). The $\mathrm{V}_{\mathrm{cyl}}$ of Acacia mangium $\left(207.48 \mathrm{~m}^{3} \mathrm{ha}^{-1}\right)$ and Jacaranda copaia (93.57 $\mathrm{m}^{3} \mathrm{ha}^{-1}$ ) were very high compared with those observed by Souza et al. (2004) in 4-year-old plantations of $A$. mangium (3 x 2 m spacing) (181.26 $\left.\mathrm{m}^{3} \mathrm{ha}^{-1}\right)$ and Tonini et al. (2006) for Jacaranda copaia in 5-year-old plantations (4 x $3 \mathrm{~m}$ spacing) $\left(17.98 \mathrm{~m}^{3}\right.$ $\left.\mathrm{ha}^{-1}\right)$. In both situations, the spacing used was higher than that used in the present study ( $2 \times 2 \mathrm{~m})$. Therefore, spacing clearly influenced our results, since a smaller spacing produces higher volumes of wood per hectare (Nascimento et al. 2012).

The better performance of Dipteryx odorata and Jacaranda copaia was correlated with the higher soil fertility (higher availability of calcium and magnesium, which influenced the highest values of $\mathrm{pH}$ and sum of bases at the depth of 0.00 $0.30 \mathrm{~m}$; Machado et al. 2017). On the other hand, the worst performance of Acacia mangium and Swietenia macrophylla was influenced by higher values of exchangeable aluminum in the soil, which can be toxic and compromise the growth and survival of most plants. Parkia decussata had intermediate performance, because of the position that this species occupied in the principal component analysis.

\section{CONCLUSIONS}

Jacaranda copaia, followed by Dipteryx odorata and Parkia decussata, are suitable for planting in areas with edaphoclimatic conditions similar to those of the present work, due to the best performance in 4-year-old monospecific experimental plantations, in comparison to Acacia mangium and Swietenia macrophylla. The lowest performance of Swietenia macrophylla was influenced by the severe attack of Hypsipylla grandella.

\section{REFERENCES}

ABRAF - Associação Brasileira de Produtores de Florestas Plantadas. 2013. Anuário estatístico ABRAF 2013 ano base 2012. ABRAF, Brasília. 148p.

Almeida, A.N.; Angelo, H.; Silva, J.C.G.L.; Hoeflich, V.A. 2010. Mercado de madeiras tropicais: substituição na demanda de exportaçáo. Acta Amazonica, 40: 119-126.

Barbosa, A.P.; Campos, M.A.A.; Sampaio, P.T.B.; Nakamura, S.; Gonçalves, C.Q.B. 2003. O crescimento de duas espécies florestais pioneiras, pau-de-balsa (Ochroma lagopus Sw.) e caroba (Jacaranda copaia D. Don), usadas para recuperação de áreas degradadas pela agricultura na Amazônia central, Brasil. Acta Amazonica, 33: 477-485.

Barros, L.S.; Vale Júnior, J.F.; Schaefer, C.E.G.R.; Mourão Júnior, M. 2009. Perdas de solo e água em plantio de Acacia mangium Wild e savana em Roraima, norte da Amazônia. Revista Brasileira de Ciência do Solo, 33: 447-454.

Condé, T.M.; Lima, M.L.M.; Lima Neto, E.M.; Tonini, H. 2013. Morfometria de quatro espécies florestais em sistemas agroflorestais no munícipio de Porto Velho, Rondônia. Revista Agroambiente, 7: 18-27.

Costa, K.C.P.; Fereira, M.J.; Linhares, A.C.C.; Guedes, A.V. 2015. Biomassa e nutrientes removidos no primeiro desbaste em plantio de Bertholletia excelsa Bonpl. Scientia Forestalis, 43: 591-600.

Dias, D.P.; Marenco, R.A. 2006. Photoinhibition of photosynthesis in Minquartia guianensis and Swietenia macrophylla inferred by monitoring the initial fluorescence. Photosynthetica, 44: 235-240.

Diniz, M.B.; Oliveira Junior, J.N.; Trompieri Neto, N.; Diniz, M.J.T. 2009. Causas do desmatamento da Amazônia: uma aplicaçáo do teste de causalidade de Granger acerca das principais fontes de desmatamento nos municípios da Amazônia Legal brasileira. Nova Economia, 19: 121-151.

Escalante, E.; Pando, V.; Saravia, P.; Bravo, F. 2012. Survival and growth of big-leaf mahogany (Swietenia macrophylla King) seedlings in two provenance trials in Bolivia. Ecología en Bolivia, 47: 37-52.

Falesi, I.C.; Cruz; E.S; Pereira, F.B.; Lopes, E.C. 1969. Os solos da área de Manaus-Itacoatiara. Instituto de Pesquisa e Experimentação Agropecuária do Norte (IPEAN), Belém. 116 p.

Galeão, R.G; Carvalho, J.O.P.; Yared, J.A.G.; Marques, L.C.T.; Costa Filho, P.P. 2006. Diagnóstico dos projetos de reposição florestal no Estado do Pará. Revista de Ciências Agrárias, 45: 101-120. 
Halfeld-Vieira, B.A.; Nechet, K.L. 2010. Doenças em Acacia mangium e danos de origem abiótica. In: Tonini, H.; Halfeld-Vieira, B.A.; Silva, S.J.R. Acacia mangium: características e seu cultivo em Roraima. Embrapa Informação Tecnológica, Brasília. p.107-117.

Hammer, Ø.; Harper, D.A.T.; Ryan, P.D. 2001. PAST: Paleontological statistics software package for education and data analysis. Palaeontologia Electronica, 4: 1-9.

IBGE - Instituto Brasileiro de Geografia e Estatística. 2010. Indicadores de Desenvolvimento Sustentável: Brasil 2010. Rio de Janeiro, RJ: [s.n.]. (http://www.ibge.gov.br/home/geociencias/ recursosnaturais/ids/ids2010.pdf). Accessed on April 22, 2016.

Ignácio, E.D.; Attanasio, C.M.; Toniato, M.T.Z. 2007. Monitoramento de plantios de restauração de florestas ciliares: microbacia do Ribeirão São João, Mineiros do Tietê, SP. Revista do Instituto Florestal, 19: 137-148.

Lunz, A.M.; Thomazini, M.J.; Moraes, M.C.B.; Neves, E.J.M.; Batista, T.F.C.; Degenhardt, J.; Sousa, L. A.; Ohashi, O. S. 2009. Hypsipyla grandella em mogno (Swietenia macrophylla): situação atual e perspectivas. Pesquisa Florestal Brasileira, 59: 45-55.

Machado, M.R.; Camara, R.; Sampaio, P.T.B.; Pereira, M.G.; Ferraz, J.B.S. 2017. Land cover changes affect soil chemical attributes in the Brazilian Amazon. Acta Scientiarum, Agronomy, 39: 385-391.

Machado, M.R.; Sampaio, P.T.B.; Ferraz, J.; Camara, R.; Pereira, M.G. 2016. Nutrient retranslocation in forest species in the Brazilian Amazon. Acta Scientiarum Agronomy, 38: 93-101.

Miranda, E.M.; Valentim, J.F. 2000. Desempenho de doze espécies arbóreas nativas e introduzidas com potencial de uso múltiplo no Estado do Acre, Brasil. Acta Amazonica, 30: 471-480.

Nascimento, D.F.; Leles, P.S.S.; Oliveira Neto, S.N.; Moreira, R.T.S.; Alonso, J.M. 2012. Crescimento inicial de seis espécies florestais em diferentes espaçamentos. Cerne, 18: 159-165.

Nunes, Y.R.F.; Fagundes, N. C.A.; Veloso, M.D.M.; Gonzaga, A.P.D.; Domingues, E.B.S.; Almeida, H.S.; Castro, G.C.; Santos, R.M. 2015. Sobrevivência e crescimento de sete espécies arbóreas nativas em uma área degradada de floresta estacional decidual, norte de Minas Gerais. Revista Árvore, 39: 801-810.

Reboita, M.S.; Gan, M.A.; Rocha, R.P.; Ambrizzi, T. 2010. Regimes de Precipitação na América do Sul: Uma Revisão Bibliográfica. Revista Brasileira de Meteorologia, 25: 185-204.

Salomão, R.P., Brienza Júnior, S; Rosa, N.A. 2014. Dinâmica de reflorestamento em áreas de restauração após mineração em unidade de conservação na Amazônia. Revista Árvore, 38: 1-24.

Sampaio, P.T.B.; Barbosa, A.P.; Fernandes, N.P. 1989. Ensaio de espaçamento com caroba - Jacaranda copaia (Aubl.) D. Don. Bignoniaceae. Acta Amazonica, 19: 383-389.

Santos Filho, B.G.; Pantoja, M.J.R.; Batista, T.F.C.; Tavares, A.E.B.; Ribeiro, R.C.; Pinheiro, H.A. 2007. Comportamento nutricional de espécies arbóreas utilizadas no reflorestamento de áreas degradadas sob o impacto da exploração petrolífera na regiāo de Urucu, Município de Coari, AM. Revista Brasileira de Biociências, 5: 1134-1136.
Silva, R.P.; Filgueiras, G.C.; Rivero, S.L.M.; Silva, M.N. 2013a. O comportamento das exportaçôes brasileiras de produtos florestais e sua posição competitiva no mercado internacional no período de 1997 a 2011. Revista de Economia, 39: 67-90.

Silva, M.C.A.; Rosa, L.S.; Vieira, T.A. 2013b. The efficiency of neem (Azadirachta indica A. Juss) as natural barrier to attack by Hypsipyla grandella (Zeller) (Lepidoptera: Pyralidae) on the Brazilian mahogany (Swietenia macrophylla King). Acta Amazonica, 43: 19-24.

Soares, C.P.B.; Paula Neto, F.P.; Souza, A.L. 2011. Dendrometria e inventário florestal. 2nd ed. Editora UFV, Viçosa. 272p.

Souza, C.R.; Rossi, L.M.B.; Azevedo, C.P.; Lima, R.M.B. 2004. Comportamento da Acacia mangium e de clones de Eucalyptus grandis $\mathrm{x}$ Eucalyptus urophylla em plantios experimentais na Amazônia Ocidental. Scientia Forestalis, 65: 95-101.

Souza, C.R.; Lima, R.M.B.; Azevedo, C.P.; Rossi, L.M.B. 2008. Desempenho de espécies florestais para uso múltiplo na Amazônia. Scientia Forestalis, 36: 7-14.

Souza, C.R.; Azevedo, C.P.; Lima, R.M.B.; Rossi, L.M.B. 2010. Comportamento de espécies florestais em plantios a pleno sol e em faixas de enriquecimento de capoeira na Amazônia. Acta Amazonica, 40: 127-134.

Stangerlin, D.M.; Costa, A.F.; Garlet, A.; Pastore, T.C.M. 2013. Resistência natural da madeira de três espécies amazônicas submetidas ao ataque de fungos apodrecedores. Revista Ciência da Madeira, 4: 15 -32.

Tonini, H.; Oliveira Junior, M.M.C.; Schwengber, D. 2008. Crescimento de espécies nativas da Amazônia submetidas ao plantio no estado de Roraima. Ciência Florestal, 18: 151-158.

Tonini, H.; Francia Arco-Verde, M.; Schwengber, D.; Mourão Junior, M. 2006. Avaliação de espécies florestais em área de mata no estado de Roraima. Cerne, 12: 8-18.

Trevisan, R.; Souza, J.T.; Denardi, L.; Haselein, C.R.; Santini, E.J. 2013. Efeito do desbaste no comprimento das fibras da madeira de Eucalyptus grandis W. Hill ex Maiden. Ciência Florestal, 23: 463-475.

Vázquez, S.P.F.; Mendonça, M.S.; Noda, S.N. 2014. Etnobotânica de plantas medicinais em comunidades ribeirinhas do Município de Manacapuru, Amazonas, Brasil. Acta Amazonica, 44: 457-472.

Vieira, I.C.G.; Toledo, P.M.; Silva, J.M.C.; Higuchi, H. 2008. Deforestation and threats to the biodiversity of Amazonia. Brazilian Journal of Biology, 68: 949-956.

Yamashita, N.; Ohta, S.; Hardjono, A. 2008. Soil changes induced by Acacia mangium plantation establishment: comparison with secondary forest and Imperata cylindrical grassland soils in South Sumatra, Indonesia. Forest Ecology and Management, 254: 362-370.

Zau, M.D.L.; Vasconcelos, R.P.; Giacon, V.M. 2014. Avaliação das propriedades química, física e mecânica de painéis aglomerados produzidos com resíduo de madeira da Amazônia - cumaru (Dipteryx odorata) e resina poliuretana à base de óleo de mamona. Polimeros, 24: 726-732.

\section{RECEIVED: $01 / 03 / 2017$ \\ ACCEPTED: 20/09/2017 \\ ASSOCIATE EDITOR: Francesco Ripullone}

